\title{
TTR
}

Traduction, terminologie, re?daction

\section{Jean-Paul Vinay and Jean Darbelnet. Comparative Stylistics of French and English, trans. and ed. by Juan C. Sager and M.-J. Hamel. Amsterdam/Philadelphia, John Benjamins, 1995.}

\section{Denise Merkle}

Volume 9, numéro 2, 2e semestre 1996

Parcours de traduction

Pathways of Translation

URI : https://id.erudit.org/iderudit/037271ar

DOI : https://doi.org/10.7202/037271ar

Aller au sommaire du numéro

Éditeur(s)

Association canadienne de traductologie

ISSN

0835-8443 (imprimé)

1708-2188 (numérique)

Découvrir la revue

Citer ce compte rendu

Merkle, D. (1996). Compte rendu de [Jean-Paul Vinay and Jean Darbelnet.

Comparative Stylistics of French and English, trans. and ed. by Juan C. Sager and M.-J. Hamel. Amsterdam/Philadelphia, John Benjamins, 1995.] TTR, 9(2),

243-246. https://doi.org/10.7202/037271ar d'utilisation que vous pouvez consulter en ligne.

https://apropos.erudit.org/fr/usagers/politique-dutilisation/ 


\section{Jean-Paul Vinay and Jean Darbelnet. Comparative Stylistics of French and English, trans. and ed. by Juan C. Sager and M.-J. Hamel. Amsterdam/Philadelphia, John Benjamins, 1995.}

For almost forty years, French-speaking students of comparative stylistics and translation have benefited greatly from Vinay and Darbelnet's classic course book Stylistigue comparée du français et de l'anglais. Through the authors' methodological approach, students have learned to appreciate and respect "le génie de la languen or the "culturespecific nature" (p. 278) of the French and English languages and the importance of consulting parallel texts in order to avoid the pitfalls to which many products of bilingual cultures, and Canadian translators in particular, are prone: linguistic interference, or anglicisms and Canadianisms. The book has become a standard textbook and sparked the development of courses on comparative stylistics and comparative grammar in many Canadian universities offering French studies and translator-training programmes. It has also made an invaluable contribution to research in applied linguistics throughout the Frenchspeaking world, yet English-speakers appear to have come into little contact with it.

Now an English version of this classic text has been prepared by Juan C. Sager and M.-J. Hamel to widen its English-speaking readership. Comparative Stylistics of French and English: $A$ methodology for translation is available for those, who are more comfortable reading applied linguistics referencematerial in English. As Sager and Hamel note: "books on translation written in English seem to be produced by monolingual speakers or at least by people who dislike reading other languiages" (p. 49). They add, "it is not surprising that only exceptionally do we find a full discussion, rather than a passing reference, to this book in English publications, while the opposite is certainly not true. The result is that until recently Vinay and Darbelnet were almost completely ignored by English-speaking writers in the United States and are only cursorily referred to in Great Britain" (p. 49). By making an English translation available, the translators hope to increase the interest of American linguists and applied linguists in ideas 
that have been circulating and contributing to the advancement of knowledge in their field, though primarily in the French-speaking world, for close to 40 years.

Sager and Hamel are once again playing the quintessential role of the translator as bridge between cultures and languages by affording, in this case, English-speaking readers more direct access to heretofore under-explored concepts. And as they point out, the contribution has been recognized not only by other language groups, but also by some English-speakers outside the United States. For example, in Translation Studies: An integrated approach (Benjamins, rev. ed. 1995; see a review of this book above), Mary Snell-Hornby refers to the usefulness of parallel text analysis in translator training, and its relevance to translation studies and lexicography. She makes specific reference to Vinay and Darbelnet's use of parallel texts as "model translations" (p. 86). Comparative Stylistics is thus intended to make these concepts more accessible to American readers; those living in States that are becoming increasingly bilingual should find it particularly useful.

But Sager and Hamel have done more than simply translate; they have updated the content and the presentation of the textbook, edited the text, added commentary, and their changes have resulted in laudable improvements to the original work. Comparative Stylistics is now broken down into four chapters that follow a clearly progressive sequence: Introduction, The Lexicon, Structures, The Message. Sample texts, the bibliography and glossary of terms complete the volume.

The translators make occasional observations about the sociolinguistic implications of bilingualism in Canada and acknowledge that bilingual populations "share a fair amount of culture" (p. 246) and thus a similar cultural point of view that makes it more difficult for them to identify with a culture (French from France) that is, in many ways, foreign to them. Nevertheless, the book's original arguments make resoundingly clear the conceptual differences between English and French and the reasons for these differences. The addition of contemporary examples from information technology, among other sources, to the comprehensive lists provided by Vinay and Darbelnet in the French publication further underline these differences. 
Each chapter ends with a detailed list of further reading suggestions in French and English, which will certainly prove invaluable to students, practitioners and researchers alike, and useful editorial comments. Chapter I gives a list of sources dealing with linguistics, language and translation; Chapter II a list of grammars, collections of faux amis, as well as reference material dealing with lexicology, word formation and neology; Chapter III a list of sources dealing with lexical categories, gender, and grammar; Chapter IV a list dealing with the types and structure of messages.

The translators' interest in terminology and documentation becomes clear through the improved glossary and updated bibliography. The glossary presentation is superior; it has been moved to the back of the book, terms have been added, entries are in English, the French equivalent has been provided between parentheses, and cross-referencing is complete. The bibliography provides a very comprehensive listing of books dealing with translation theory published since 1970 . The translators have also added two non-literary texts dealing with technical subject matter to the collection of texts that "demonstrate the move from theory to practice" (p. 292). The translators have provided their own translations and commentary and thus clearly demonstrate the practical application of Vinay and Darbelnet's methodology.

Subsequent editions of this textbook will allow for minor improvements to be made to the English version: ensuring that all texts in the bibliography appear in alphabetical order, updating some examples, correcting typesetting and typographical errors.

Comparative Stylistics of French and English is an invaluable course book for the teaching of comparative stylistics and the training of translators and, as such, will fill a void that has existed for too long in the English-speaking translation literature. It will inevitably become a standard reference book for the English-speaking world as it has been for the French-speaking world since 1958. Students will appreciate its methodological approach to translator training and comparative stylistics, detailed and up-to-date index and bilingual glossary; translators will find it a handy reference manual for translation problems. As the French version has contributed to advances in applied linguistics, comparative stylistics and translation studies in the French- 
speaking world, this English edition will certainly motivate innovative research initiatives and approaches in these areas in the Englishspeaking world.

Denise Merkle

Laurentian University 